\title{
IDENTIFIKASI AWAL WILAYAH PENGARUH KA KOMUTER DENGAN MENGGUNAKAN ANGKUTAN UMUM PENGUMPAN
}

\author{
Anita Susanti ${ }^{1}$, Ria Asih Aryani Soemitro ${ }^{2}$, Hitapriya Suprayitno ${ }^{2}$ \\ ${ }^{1}$ Mahasiswa / Institut Teknologi Sepuluh Nopember \\ ${ }^{2}$ Institut Teknologi Sepuluh Nopember \\ Email: anitasusanti.pasmar@gmail.com
}

\begin{abstract}
The public perception that the quality of public transport service is very bad cause the number of private vehicle users is very high compared with the number of users of public transport. Therefore, an initial identification of the Commuter Train influence area by feeder is required. The goal is to know how big the area of the Commuter Train influence area viewed from the use of public transport feeder on the way to and leave the station. The method used in this initial identification is the collection of primary data by conducting interview survey of SUSI Commuter Train and the SULAM Commuter Train. Survey is conducted from two different directions in the morning departure hours only. The result of initial identification is known that the city of Surabaya has the Commuter Train influence area of SUSI Commuter Train and the SULAM Commuter Train 2 different directions in the morning departure hour by using feeder to the origin station of 9000 meters (20\%) and from the destination station of 6000 meter (63.64\%).
\end{abstract}

Keywords: initial identification, influence area, feeder, Commuter Train

\section{PENDAHULUAN}

Manusia dalam melakukan aktivitasnya sehari-hari khususnya dalam perjalanan jarak jauh selalu membutuhkan kendaraan sebagai sarana transportasi. Sarana transportasi sangat beraneka ragam jenisnya meliputi transportasi darat, transportasi laut dan transportasi udara. Ketersediaan jenis transportasi yang beraneka ragam harus memenuhi beberapa kualitas pelayanan seperti halnya kehandalan, waktu perjalanan, biaya, kenyaman, dan keamanan yang diinginkan oleh penggunanya [11]. Beberapa aspek lainnya yang terkait dengan standar pelayanan adalah frekuensi dan headway. Pada salah satu penelitian dilakukan penilaian terhadap 55 mikrolet di Kota Surabaya yang diamati dan hasilnya hanya 4 mikrolet saja yang memiliki nilai headway dan frekuensi sesuai dengan standart Ditjen Perhubungan Darat [1]. Kenyataan di atas menyebabkan terjadinya perbandingan pengguna kendaraan pribadi yang tidak sebanding dengan pengguna angkutan umum 1:27 yang terjadi di Kota Surabaya [12]. Perbandingan yang tidak seimbang antara pengguna kendaraan pribadi dengan pengguna angkutan umum di Kota Surabaya tersebut disebakan karena peningkatan jumlah kendaraan pribadi sebesar $8,3 \%$ per tahun dan angka pertumbuhan transportasi publik yang hanya sebesar $0,9 \%$ per tahun [13]. Pertumbuhan transportasi publik yang sangat kecil menyebabkan pengguna angkutan umum hanya didominasi oleh masyarakat dari kalangan bawah dan sebagian kalangan menengah [5].

Persepsi masyarakat terutama masyarakat dari kalangan atas terhadap kualitas pelayanan angkutan umum masih sangat rendah. Kurangnya minat masyarakat terhadap angkutan umum menyebabkan terjadinya kemacetan lalu lintas. Kemacetan lalu lintas yang disebabkan oleh peningkatan penggunaan kendaraan pribadi menjadi permasalahan utama di beberapa negara Asia seperti Taiwan, Indonesia, Malaysia, dan Vietnam [3]. Permasalahan kemacetan lalu lintas menyebabkan terjadinya peningkatan kapasitas jalan yang berdampak pada nilai derajat kejenuhan yang sangat tinggi di beberapa ruas 
jalan. Pada beberapa ruas jalan di Kota Surabaya seperti halnya Ruas Jalan A.Yani, Ruas Jalan Wonokromo dan Ruas Jalan Dupak memiliki nilai derajat kejenuhan lebih besar $>1$ [14].

Penumpukan jumlah kendaraan membutuhkan suatu solusi yang tepat dalam meminimalkan kemacetan lalu lintas. Pemerintah Kota Surabaya pada tahun 2004 menyediakan layanan KA Komuter SUSI (Surabaya-Sidoarjo) untuk mengatasi kemacetan lalu lintas terutama pada Ruas Jalan A.Yani sebagai pintu masuk utamanya Kota Surabaya. Pada kenyatannya keberadaan layanan KA SUSI kurang diminati oleh masyarakat, dimana terjadi perbandingan yang tidak seimbang antara supply dan demand terutama di jam-jam tidak sibuk dengan rentang nilai yang sangat besar [11]. Keberadaan KA sebagai salah satu angkutan umum massal yang memiliki jalur sendiri menjadi tumpuan harapan bagi Pemerintah Kota Surabaya dan negara-negara lain di dunia dalam mengatasi permasalahan kemacetan yang ada. Hongkong dan Shanghai merupakan salah satu kota besar di Asia yang mengandalkan KA sebagai salah satu solusi dalam mengatasi kemacetan lalu lintas dengan melakukan pengembangan jalur rel KA yang baru [4].

Upaya mengatasi kemacetan lalu lintas dengan mengandalkan keberadaan KA juga dilakukan oleh Pemerintah Kota Surabaya. Pada kenyataannya kemacetan lalu lintas di Kota Surabaya masih terus meningkat. Hal tersebut semakin diperburuk dengan keterbatasan bentangan layanan jalur rel KA di Kota Surabaya [9].
Oleh karena itu diperlukan identifikasi awal wilayah pengaruh KA Komuter dengan menggunakan angkutan umum pengumpan. Paper ini membahas mengenai jarak perjalanan dari angkutan umum pengumpan yang digunakan oleh penumpang KA pada saat menuju dan meninggalkan stasiun. Tujuan dilakukannya penulisan paper ini untuk mengetahui seberapa besar wilayah pengaruh KA Komuter ditinjau dari penggunaan angkutan umum pengumpan pada saat menuju dan meninggalkan stasiun.

\section{KAJIAN PUSTAKA}

\subsection{Layanan KA Komuter di Kota Surabaya}

Jenis-jenis KA Komuter yang di Kota Surabaya berdasarkan identifikasi awal adalah KA Penataran; KA Tumapel; KA Dhoho; KA KRD Sidoarjo-Bojonegoro; KA KRD Surabaya-Kertosono; KA Arjuno; KA Komuter SUSI (Surabaya-Sidoarjo); KA Komuter SULAM (Surabaya-Lamongan) [8].

Layanan KA Komuter tersebut dalam operasionalnya didukung oleh keberadaan 14 stasiun yang ada di Kota Surabaya yaitu Stasiun Semut (A), Stasiun Gubeng (B), Stasiun Pasar Turi (E), Stasiun Wonokromo (C), Shelter Ngagel (a), Shelter Margorejo (b), Shelter Jemursari (c), Shelter Kertomenanggal (d), Stasiun Waru (D), Stasiun Tandes (Z), Stasiun Kandangan (Y), Stasiun Benowo (X) Stasiun Cerme (W), dan Stasiun Sepanjang (F) [9] dan ditunjukkan pada Gambar 1.

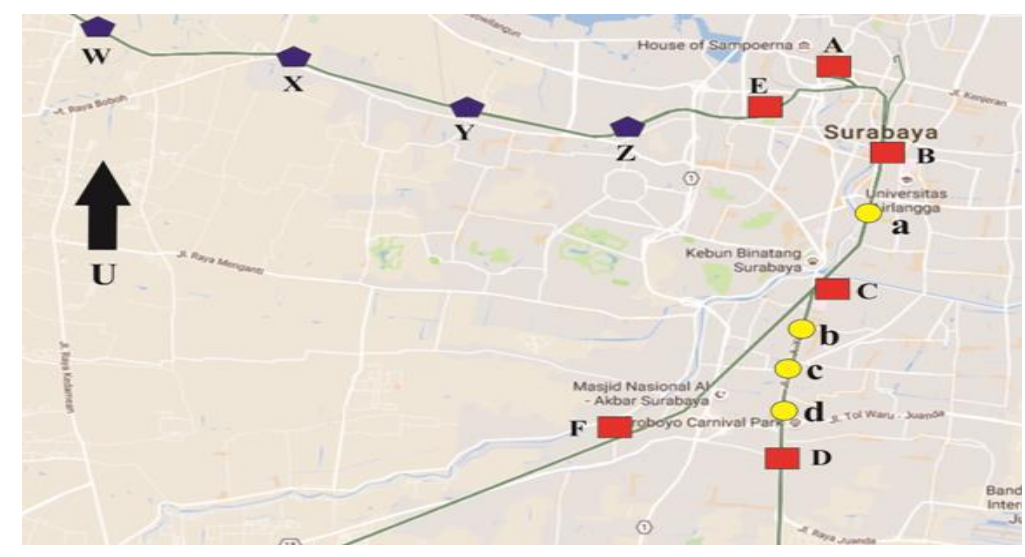

Gambar 1. Peta jalur Stasiun KA penumpang di Kota Surabaya 


\subsection{Pergerakan Masyarakat dengan Menggunakan Moda Penghubung}

Pergerakan masyarakat komuter yang menggunakan angkutan umum di Kota Athens didukung oleh berbagai jenis layanan moda penghubung. Layanan dari berbagai jenis moda penghubung tersebut disediakan untuk menghubungkan stasiun dengan pelabuhan, stasiun dengan bandara begitu juga sebaliknya. Jenis-jenis moda penghubung tersebut adalah metro line, bus perkotaan, kereta di pinggiran kota, taksi, kereta antarkota, dan bus pariwisata yang ditunjukkan pada tabel 1 [2].

Tabel 1. Perpindahan distribusi yang melalui Stasiun KA dan Pelabuhan Piraeus di Kota Athens

\begin{tabular}{|c|c|c|c|c|c|c|}
\hline \multirow{2}{*}{\multicolumn{2}{|c|}{ In }} & \multicolumn{3}{|c|}{ Stasiun KA antar kota "Stamos Larisis" } & \multicolumn{2}{|c|}{$\begin{array}{c}\text { Pelabuhan antar kota } \\
\text { "Piraeus" }\end{array}$} \\
\hline & & $\begin{array}{c}\text { KA } \\
\text { Pinggiran } \\
\text { Kota }\end{array}$ & Metro & $\begin{array}{c}\text { Bus } \\
\text { Perkotaan }\end{array}$ & Metro & $\begin{array}{c}\text { Bus } \\
\text { Perkotaan }\end{array}$ \\
\hline Metroline & & $67,50 \%$ & - & $12,43 \%$ & - & $60,25 \%$ \\
\hline Bus Perkotaan & & $3,38 \%$ & $1,82 \%$ & $27,51 \%$ & $44,23 \%$ & $22,12 \%$ \\
\hline KA Pinggiran Kota & & - & $8,49 \%$ & $1,33 \%$ & - & - \\
\hline Pengemudi Mobil & & $3,43 \%$ & $3,03 \%$ & $1,01 \%$ & $146 \%$ & $0,31 \%$ \\
\hline Penumpang Mobil & & $3,43 \%$ & $2,12 \%$ & $2,69 \%$ & $2,80 \%$ & $0,98 \%$ \\
\hline Taksi & & $7,69 \%$ & $0,91 \%$ & $1,33 \%$ & $3,77 \%$ & $0,76 \%$ \\
\hline Jalan Kaki & & $8,56 \%$ & $57,57 \%$ & $44,62 \%$ & $47,63 \%$ & $15,58 \%$ \\
\hline KA Antar Kota & & $6,00 \%$ & $26,06 \%$ & $8,73 \%$ & - & - \\
\hline Bus Pariwisata & & $0,00 \%$ & $0,00 \%$ & $0,35 \%$ & $0,12 \%$ & $0,00 \%$ \\
\hline Total & & $100,00 \%$ & $100,00 \%$ & $100,00 \%$ & $100,00 \%$ & $100,00 \%$ \\
\hline
\end{tabular}

Moda penghubung yang disediakan di Kota Khon Kaen Thailand adalah pelayanan dengan menggunakan moda BRT. Pada pengoperasiannya layanan BRT tersebut dibedakan menjadi dua, yaitu 1). BRT adalah layanan tanpa taman dan parkir, 2). BRTS yaitu layanan dengan taman dan parkir [6].

Pergerakan pelaku perjalanan sebelum menggunakan BRT Mamminasata adalah sepeda motor sebesar $51 \%$, setelah turun dari BRT Mamminasata di dominasi dengan berjalan kaki sebesar $71 \%$. Interval jarak perjalanan sebelum menggunakan BRT Mamminasata di Kota Makasar pada koridor 2 dan koridor 3 sebesar $0-3 \mathrm{~km}$. Interval jarak perjalanan sesudah menggunakan BRT Mamminasata di Kota Makasar pada koridor 2 dan koridor 3 sebesar 0 - 1,5 km [7].

\subsection{Layanan Angkutan Umum di Kota Surabaya}

Kota Kota Surabaya memiliki berbagai macam jenis layanan angkutan umum.
Angkutan umum yang dapat berfungsi sebagai angkutan umum pengumpan adalah bus kota, mikrolet dan taksi. Pada Tabel 2 akan ditunjukkan berbagai macam jenis angkutan umum menurut Dinas Perhubungan Kota Surabaya 2015.

Tabel 2. Jumlah angkutan umum di Kota Surabaya

\begin{tabular}{ccc}
\hline $\begin{array}{c}\text { Jenis Angkutan } \\
\text { Umum }\end{array}$ & $\begin{array}{c}\text { Jumlah } \\
\text { Trayek }\end{array}$ & $\begin{array}{c}\text { Jumlah } \\
\text { Armada }\end{array}$ \\
\hline Mikrolet & 58 & 4.721 \\
\hline Bus Kota & 22 & 274 \\
\hline Taksi & 24 & 4.0893 \\
\hline
\end{tabular}

Pada identifikasi awal diketahui ada beberapa layanan angkutan umum pengumpan yang melintas di tiap-tiap stasiun pemberhentian KA Komuter. Jumlah dan jenis angkutan umum yang melintas bervariasi [10] dan ditunjukkan pada Tabel 3. 
Tabel 3. Angkutan umum pengumpan yang melintas di tiap-tiap stasiun di Kota Surabaya

\begin{tabular}{|c|c|c|c|c|}
\hline $\begin{array}{l}\text { Nama-Nama } \\
\text { Stasiun }\end{array}$ & $\begin{array}{c}\text { Kelas } \\
\text { Stasiun }\end{array}$ & $\begin{array}{l}\text { Ketersediaan } \\
\text { Terminal }\end{array}$ & Angkutan Umum Pengumpan & $\begin{array}{c}\text { Jumlah } \\
\text { Angkutan Umum } \\
\text { Pengumpan } \\
\end{array}$ \\
\hline $\begin{array}{c}\text { Stasiun } \\
\text { Surabaya Kota } \\
\text { (Semut) }\end{array}$ & Besar & Tidak Ada & $\begin{array}{c}\text { Mikrolet M, Mikrolet RI, Mikrolet UBB, Bus } \\
\text { Damri }\end{array}$ & 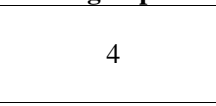 \\
\hline Stasiun Gubeng & Besar & Tidak Ada & $\begin{array}{l}\text { Mikrolet F, Mikrolet GS, Mikrolet N, } \\
\text { Mikrolet C, Mikrolet JK, Mikrolet T2, } \\
\text { Mikrolet W, Mikrolet WB. }\end{array}$ & 8 \\
\hline Shelter Ngagel & Kecil & Tidak Ada & Mikrolet W, Mikrolet WB & 2 \\
\hline $\begin{array}{c}\text { Stasiun } \\
\text { Wonokromo }\end{array}$ & Sedang & Ada & $\begin{array}{c}\text { Mikrolet H4W, Mikrolet JSP, Mikrolet N, } \\
\text { Bison }\end{array}$ & 4 \\
\hline $\begin{array}{c}\text { Shelter } \\
\text { Margorejo }\end{array}$ & Kecil & Tidak Ada & $\begin{array}{l}\text { Mikrolet H4J, Mikrolet H4W, Mikrolet JSP, } \\
\text { Mikrolet X, Bison, Bus Damri }\end{array}$ & 6 \\
\hline $\begin{array}{l}\text { Shelter } \\
\text { Jemursari }\end{array}$ & Kecil & Tidak Ada & Mikrolet X, Bison, Mikrolet JSP, Bus Damri & 4 \\
\hline $\begin{array}{c}\text { Shelter } \\
\text { Kertomenanggal }\end{array}$ & Kecil & Tidak Ada & Mikrolet X, Bison, Mikrolet JSP, Bus Damri & 4 \\
\hline Stasiun Waru & Kecil & Tidak Ada & Mikrolet X, Bison, Mikrolet JSP & 3 \\
\hline $\begin{array}{l}\text { Stasiun } \\
\text { Sepanjang }\end{array}$ & Kecil & Tidak Ada & $\begin{array}{c}\text { Mikrolet BJ, Bus Kota P5, Bus Kota P3, Bus } \\
\text { Kota F, Mikrolet BP, Mikrolet C, Mikrolet D, } \\
\text { Mikrolet LMJ, Mikrolet Q, Mikrolet RT, } \\
\text { Mikrolet WK }\end{array}$ & 11 \\
\hline $\begin{array}{c}\text { Stasiun Pasar } \\
\text { Turi }\end{array}$ & Besar & Tidak Ada & Mikrolet E, Mikrolet BP, Mikrolet I & 3 \\
\hline Stasiun Tandes & Kecil & Tidak Ada & Mikrolet E, Mikrolet BP, Mikrolet I & 3 \\
\hline $\begin{array}{c}\text { Stasiun } \\
\text { Kandangan }\end{array}$ & Kecil & Tidak Ada & Mikrolet I, Mikrolet Z, Mikrolet Z1 & 4 \\
\hline Stasiun Benowo & Kecil & $\begin{array}{c}\text { Ada } \\
\text { (Jarak } \pm 1 \text { km dari } \\
\text { Stasiun Benowo) } \\
\end{array}$ & Mikrolet LMJ, Mikrolet M & 2 \\
\hline Stasiun Cerme & Kecil & Tidak Ada & Mikrolet H1, Mikrolet H2, Mikrolet G & 3 \\
\hline
\end{tabular}

\section{METODE PENELITIAN}

Pada identifikasi awal ini metode yang digunakan adalah pengumpulan data sekunder dan data primer. Data primer diperoleh dari survai wawancara terhadap penumpang KA Komuter SUSI (Surabaya-Sidoarjo) dan KA Komuter SULAM (Surabaya-Lamongan) terkait angkutan umum pengumpan yang digunakan sebelum dan sesudah menggunakan KA Komuter. Tujuan dilakukannya survai wawancara tersebut untuk mengetahui jarak perjalanan pada saat menuju dan meninggalkan stasiun. Hal tersebut penting untuk dilakukan guna mengetahui sebarapa besar wilayah pengaruh KA Komuter di Kota Surabaya dilihat dari jarak perjalanan penumpang KA dengan menggunakan angkutan umum pengumpan.

\section{HASIL DAN PEMBAHASAN}

4.1 Definisi Wilayah Pengaruh KA Komuter di Kota Surabaya dengan Menggunakan Angkutan Umum Pengumpan

Wilayah pengaruh KA Komuter di Kota Surabaya dengan menggunakan angkutan umum pengumpan adalah wilayah dimana pelaku perjalanan pada saat menuju dan meninggalkan stasiun masih merasa nyaman menggunakan angkutan umum pengumpan. Jenis-jenis layanan angkutan umum pengumpan yang diamati pada penulisan paper ini adalah bus kota, mikrolet dan juga becak pada saat menuju dan meninggalkan stasiun dan ditunjukkan pada Gambar 2. 


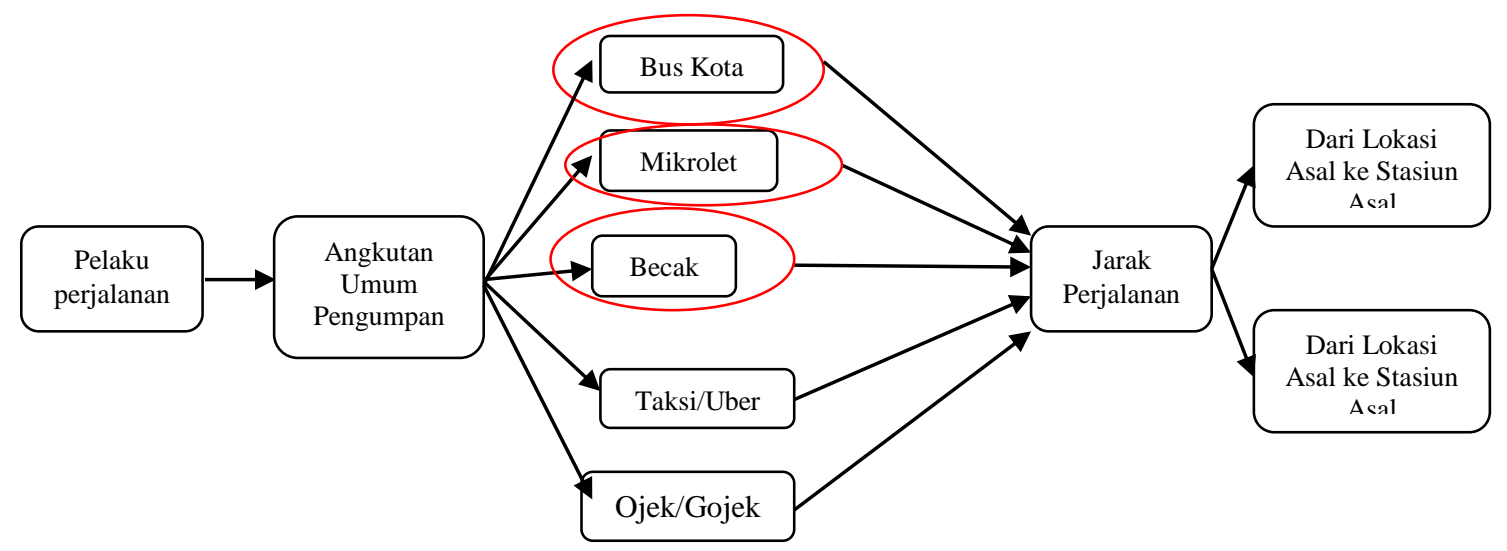

Gambar 2. Jenis-Jenis Layanan Angkutan Umum Pengumpan

4.2 Jumlah Penumpang KA Komuter SUSI Dilihat dari Angkutan Umum Pengumpan yang Digunakan

Jumlah penumpang KA Komuter SUSI yang menggunakan angkutan umum pengumpan dari hasil survai wawancara terhadap 50 orang penumpang arah SurabayaSidoarjo dan 57 orang penumpang arah Sidoarjo-Surbaya yang dilakukan pada tanggal 25 April 2017 (hari kerja) di jam keberangkatan pagi hari saja ditunjukkan pada Tabel 4 dan Tabel 5.

Tabel 4. Jumlah pengguna angkutan umum pengumpan menuju ke stasiun dan dari stasiun di jam keberangkatan pagi hari (04.10-04.54) dari arah Surabaya-Sidoarjo

\begin{tabular}{|c|c|c|c|c|c|c|c|}
\hline \multicolumn{4}{|c|}{ Menujun Stasiun } & \multicolumn{4}{|c|}{ Meninggalkan Stasiun } \\
\hline Jenis AUP & $\begin{array}{c}\text { Interval Jarak } \\
\text { perjalanan } \\
\text { (meter) }\end{array}$ & $\begin{array}{l}\text { Jumlah } \\
\text { (orang) }\end{array}$ & $\begin{array}{c}\text { Prosentase } \\
(\%)\end{array}$ & Jenis AUP & $\begin{array}{c}\text { Interval } \\
\text { Jarak } \\
\text { perjalanan } \\
\text { (meter) }\end{array}$ & $\begin{array}{l}\text { Jumlah } \\
\text { (orang) }\end{array}$ & $\begin{array}{c}\text { Prosentase } \\
(\%)\end{array}$ \\
\hline \multirow{3}{*}{ Mikrolet } & $0-3000$ & 0 & $0 \%$ & \multirow{3}{*}{ Mikrolet } & $0-3000$ & 1 & $16.67 \%$ \\
\hline & $3000-6000$ & 8 & $80 \%$ & & $3000-6000$ & 2 & $33.33 \%$ \\
\hline & $6000-9000$ & 2 & $20 \%$ & & $6000-9000$ & 3 & $50 \%$ \\
\hline \multicolumn{2}{|c|}{ Total } & 10 & $100 \%$ & \multicolumn{2}{|c|}{ Total } & 6 & $100 \%$ \\
\hline
\end{tabular}

Tabel 5. Jumlah pengguna angkutan umum pengumpan menuju ke stasiun dan dari stasiun di jam keberangkatan pagi hari (05.45-07.05) dari arah Sidoarjo-Surabaya

\begin{tabular}{|c|c|c|c|c|c|c|c|}
\hline \multicolumn{4}{|c|}{ Menujun Stasiun } & \multicolumn{4}{|c|}{ Meninggalkan Stasiun } \\
\hline Jenis AUP & $\begin{array}{c}\text { Interval } \\
\text { Jarak } \\
\text { perjalanan } \\
\text { (meter) }\end{array}$ & $\begin{array}{l}\text { Jumlah } \\
\text { (orang) }\end{array}$ & $\begin{array}{c}\text { Prosentase } \\
(\%)\end{array}$ & Jenis AUP & $\begin{array}{c}\text { Interval } \\
\text { Jarak } \\
\text { perjalanan } \\
\text { (meter) }\end{array}$ & $\begin{array}{l}\text { Jumlah } \\
\text { (orang) }\end{array}$ & $\begin{array}{c}\text { Prosentase } \\
(\%)\end{array}$ \\
\hline \multirow{3}{*}{ Mikrolet } & $0-2000$ & 0 & $0 \%$ & \multirow{3}{*}{ Mikrolet } & $0-2000$ & 0 & $0 \%$ \\
\hline & $2000-4000$ & 0 & $0 \%$ & & $2000-4000$ & 4 & $36.36 \%$ \\
\hline & $4000-6000$ & 3 & $100 \%$ & & $4000-6000$ & 7 & $63.64 \%$ \\
\hline \multicolumn{2}{|c|}{ Total } & 3 & $100 \%$ & \multicolumn{2}{|c|}{ Total } & 11 & $100 \%$ \\
\hline
\end{tabular}

\subsection{Jumlah Penumpang KA}

Komuter SULAM Dilihat dari Angkutan Umum Pengumpan yang Digunakan
Jumlah penumpang yang menggunakan angkutan umum pengumpan berdasarkan hasil survai wawancara terhadap 54 orang penumpang arah Surabaya-Lamongan begitu juga sebaliknya dan dilakukan pada hari kerja tanggal 26 April 2017 di jam keberangkatan pagi hari saja ditunjukkan pada Tabel 6 dan Tabel 7. 
Tabel 6. Jumlah Pengguna Angkutan Umum Pengumpan Menuju ke Stasiun dan Dari Stasiun di di Jam Keberangkatan Pagi Hari (04.05-05.06) dari arah Surabaya-Lamongan

\begin{tabular}{|c|c|c|c|c|c|c|c|}
\hline \multicolumn{4}{|c|}{ Menujun Stasiun } & \multicolumn{4}{|c|}{ Meninggalkan Stasiun } \\
\hline Jenis AUP & $\begin{array}{c}\text { Interval } \\
\text { Jarak } \\
\text { perjalanan } \\
\text { (meter) }\end{array}$ & $\begin{array}{l}\text { Jumlah } \\
\text { (orang) }\end{array}$ & $\begin{array}{c}\text { Prosentase } \\
(\%)\end{array}$ & Jenis AUP & $\begin{array}{c}\text { Interval Jarak } \\
\text { perjalanan } \\
\text { (meter) }\end{array}$ & $\begin{array}{l}\text { Jumlah } \\
\text { (orang) }\end{array}$ & $\begin{array}{c}\text { Prosentase } \\
(\%)\end{array}$ \\
\hline \multirow{3}{*}{ Mikrolet } & $0-1500$ & 0 & $0 \%$ & Mikrolet & 5100 & 3 & $18.75 \%$ \\
\hline & $1500-3000$ & 8 & $53.33 \%$ & \multirow{2}{*}{ Bus Kota } & $0-6000$ & 0 & $0 \%$ \\
\hline & $3000-4500$ & 7 & $46.67 \%$ & & $6000-12000$ & 13 & $81.25 \%$ \\
\hline \multicolumn{2}{|c|}{ Total } & 15 & $100 \%$ & & otal & 16 & $100 \%$ \\
\hline
\end{tabular}

Tabel 7. Jumlah Pengguna Angkutan umum pengumpan Menuju ke Stasiun dan Dari Stasiun di di Jam Keberangkatan Pagi Hari (05.30-06.45) dari arah Lamongan-Surabaya

\begin{tabular}{|c|c|c|c|c|c|c|c|}
\hline \multicolumn{4}{|c|}{ Menujun Stasiun } & \multicolumn{4}{|c|}{ Meninggalkan Stasiun } \\
\hline Jenis AUP & $\begin{array}{c}\text { Interval } \\
\text { Jarak } \\
\text { perjalanan } \\
\text { (meter) }\end{array}$ & $\begin{array}{l}\text { Jumlah } \\
\text { (orang) }\end{array}$ & $\begin{array}{c}\text { Prosentase } \\
(\%)\end{array}$ & Jenis AUP & $\begin{array}{c}\text { Interval } \\
\text { Jarak } \\
\text { perjalanan } \\
\text { (meter) }\end{array}$ & $\begin{array}{l}\text { Jumlah } \\
\text { (orang) }\end{array}$ & $\begin{array}{c}\text { Prosentase } \\
(\%)\end{array}$ \\
\hline \multirow{4}{*}{ Mikrolet } & $0-1500$ & 0 & $0 \%$ & Mikrolet & $0-1500$ & 0 & $0 \%$ \\
\hline & $1500-3000$ & 0 & $0 \%$ & \multirow{3}{*}{ Bus Kota } & $1500-3000$ & 20 & $76.92 \%$ \\
\hline & $3000-4500$ & 3 & $21.43 \%$ & & $3000-4500$ & 0 & $0 \%$ \\
\hline & $4500-6000$ & 11 & $78.57 \%$ & & $4500-6000$ & 6 & $23.08 \%$ \\
\hline \multicolumn{2}{|c|}{ Total } & 14 & $100 \%$ & \multicolumn{2}{|c|}{ Total } & 26 & $100 \%$ \\
\hline
\end{tabular}

\subsection{Wilayah Pengaruh KA Komuter} SUSI dan KA Komuter SULAM dengan menggunakan Angkutan Umum Pengumpan

KA Komuter SUSI dari arah Surabaya-Sidoarjo memiliki wilayah pengaruh dilihat dari angkutan umum pengumpan yang digunakan oleh penumpang menuju ke stasiun asal sebesar 9000 meter. Wilayah pengaruh KA Komuter SUSI pada saat meninggalkan stasiun tujuan sebesar 5000 meter. Wilayah pengaruh KA Komuter SUSI dari arah Sidoarjo-Surabaya pada saat menuju ke stasiun asal sebesar 6000 meter dan meninggalkan stasiun tujuan sebesar 6000 meter. Wilayah pengaruh KA Komuter SUSI dari dua arah yang berbeda di jam keberangkatan pagi hari ditunjukkan pada Gambar 3.

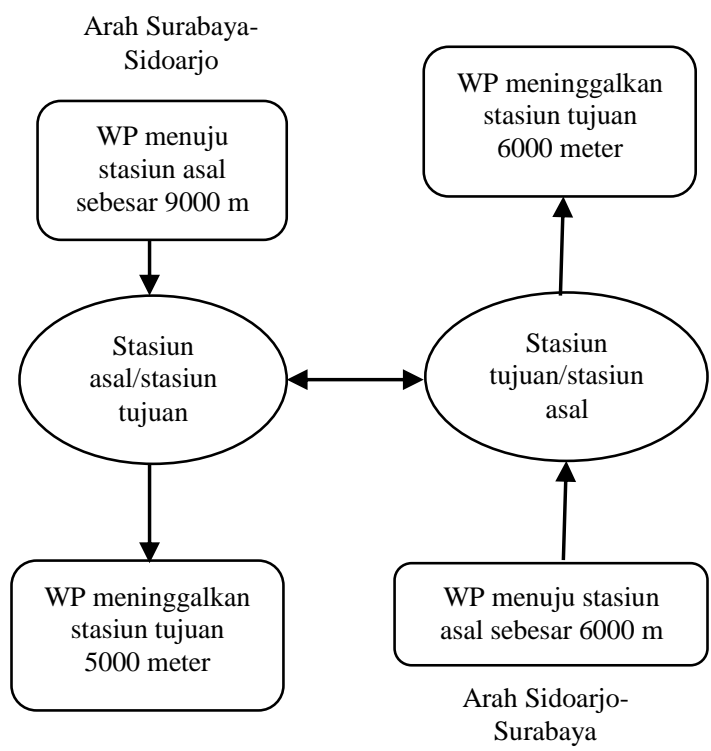

Gambar 3. WP KA Komuter SUSI 
KA Komuter SULAM dari arah Surabaya-Lamongan memiliki wilayah pengaruh dilihat dari angkutan umum pengumpan yang digunakan oleh penumpang menuju ke stasiun asal sebesar 6000 meter. Wilayah pengaruh KA Komuter SULAM pada saat meninggalkan stasiun tujuan sebesar 12000 meter. Wilayah pengaruh KA Komuter SULAM dari arah LamonganSurabaya pada saat menuju ke stasiun asal sebesar 5000 meter dan meninggalkan stasiun tujuan sebesar 4000 meter. Wilayah pengaruh KA Komuter SULAM dari dua arah yang berbeda di jam keberangkatan pagi hari ditunjukkan pada Gambar 4.

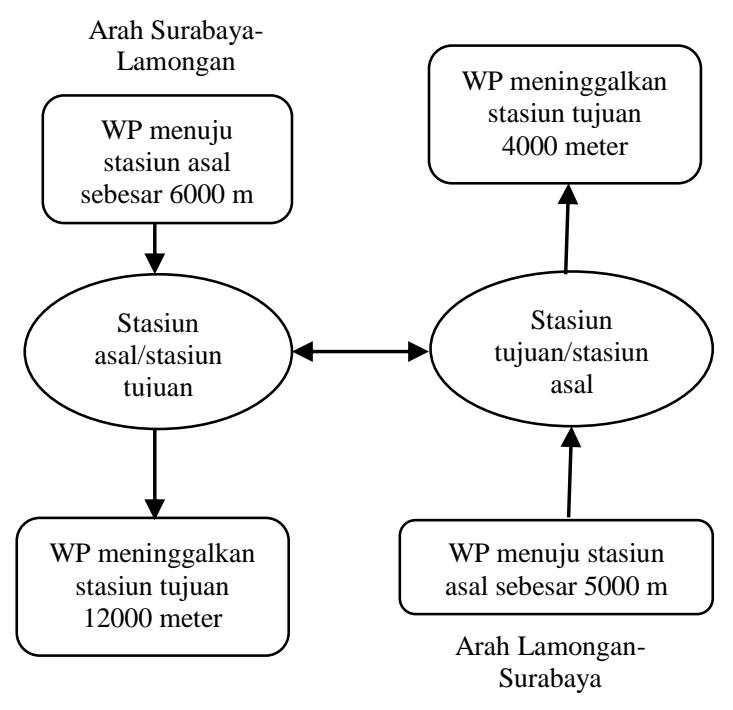

Gambar 4. WP KA Komuter SULAM

Kota Surabaya memiliki wilayah pengaruh KA Komuter SUSI dan KA Komuter SULAM di jam keberangkatan pagi hari saja dengan menggunakan angkutan umum pengumpan menuju ke stasiun sebesar 9000 meter (20\%) dan dari stasiun sebesar 6000 meter (50\%) ditunjukkan pada Gambar 5.

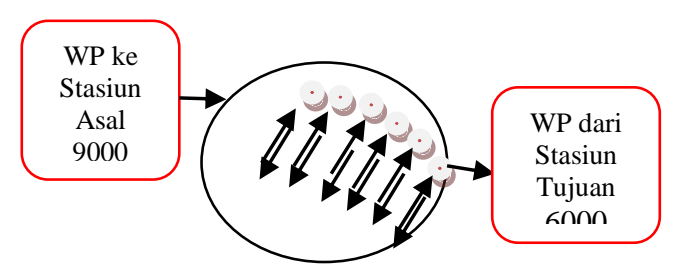

Gambar 5. WP KA Komuter di Kota Surabaya

\section{KESIMPULAN}

KA Komuter SUSI dari arah SurabayaSidoarjo begitu juga sebaliknya memiliki wilayah pengaruh dilihat dari moda penghubung (angkutan umum pengumpan) sebagai berikut:

a. Wilayah pengaruh menuju ke stasiun asal sebesar 9000 meter (20\%) arah Surabaya-Sidoarjo.

b. Wilayah pengaruh pada saat meninggalkan stasiun tujuan sebesar 6000 (50\%) meter arah SurabayaSidoarjo.

c. Wilayah pengaruh menuju ke stasiun asal sebesar 6000 meter (100\%) arah Sidoarjo-Surabaya.

d. Wilayah pengaruh pada saat meninggalkan stasiun tujuan sebesar $6000(63.64 \%)$ meter arah SidoarjoSurabaya.

KA Komuter SULAM dari arah Surabaya-Lamongan begitu juga sebaliknya memiliki wilayah pengaruh dilihat dari moda penghubung (angkutan umum pengumpan) sebagai berikut:

a. Wilayah pengaruh menuju ke stasiun asal sebesar 4000 meter $(46.67 \%)$ arah Surabaya-Lamongan.

b. Wilayah pengaruh pada saat meninggalkan stasiun tujuan sebesar 12000 meter (81.25\%) arah Surabaya-Lamongan.

c. Wilayah pengaruh menuju ke stasiun asal sebesar 5100 meter $(78.57 \%)$ arah Lamongan-Surabaya.

d. Wilayah pengaruh pada saat meninggalkan stasiun tujuan sebesar 4000 meter $(23.08 \%)$ arah Lamongan-Surabaya.

Kota Surabaya memiliki wilayah pengaruh KA Komuter SUSI dan KA Komuter SULAM di jam keberangkatan pagi hari saja dengan menggunakan angkutan umum pengumpan menuju ke stasiun sebesar 9000 meter $(20 \%)$ dan dari stasiun sebesar 6000 meter $(50 \%)$. Hasil identifikasi hanya diketahui wilayah pengaruh KA Komuter ditinjau dari angkutan umum pengumpan. Oleh karena itu diperlukan identifikasi lanjutan mengenai wilayah pengaruh KA Komuter dengan menggunakan mobil. 


\section{DAFTAR PUSTAKA}

[1]. Atho, M. (2013). Evaluasi Kinerja Pelayanan Jasa Angkutan Umum Jenis Mikrolet di Kota Surabaya", Jurnal Pendidikan Geografi Swara Bumi UNESA, Vol. 2, No. 1, halaman 276-284.

[2]. Latinopoulou, M.P. \& Iordanopoulos, P. (2012). "Intermodal Passengers Terminal: Design standars for better level of service", Procedia-Social and Behavioral, 48, pp. 3297-3306.

[3]. Le, T.Q. \& Nurhidayanti, Z.A. (2016). “A Study of Motorcycle Lane Design in Some Asian Countries", Procedia Engineering, 142, pp. 292-298.

[4]. Li, Z.C., Lam, W.H.K., Wong, S.C. \& Sumalee, A. (2011). "Design Of a Rail Transit Line for Profit Maximization in a Linear Transportation Corridor', Procedia Socal \& Behavioral Science, 17, pp. 82-112.

[5]. Munawar, A. (2007). "Pengembangan Transportasi Yang Berkelanjutan”, Pidato Pengukuhan Guru Besar, Universitas Gajah Mada.

[6]. Satiennam, T., Jaensisrisak, S., Satiennam, W. \& Detdamrong, S. (2016). "Potensial for Modal Shift by Passenger Car \& Motorcycle Users Towards Bus Rapid Transit (BRT) in an Asian Developing City". IATSS Research, 39, pp. 121-129.

[7]. Suprayitno, H. \& Upa, V.A. (2016). "Mamminasata BRT User Trip Characteristics for the Design of Demand \& Modelling Method for a New BRT Line", The Journal for Technology \& Science, Vol. 27, No. 3, December, FTSP ITS, Surabaya.

[8]. Susanti, A., Soemitro, R.A.A. \& Suprayitno, H. (2017). "Identifikasi Awal Layanan Angkutan Kereta Api Untuk Perjalanan Orang di Kota Surabaya”, E-Journal Rekayasa Teknik Sipil (REKATS) UNESA, Vol. 1, No. 1, halaman 332-335.
[9]. Susanti, A., Soemitro, R.A.A. \& Suprayitno, H. (2017). "Identifikasi Awal Jalur KA Untuk Perjalanan Orang di Kota Surabaya", E-Journal Rekayasa Teknik Sipil (REKATS) UNESA, Vol. 1, No. 1, halaman 446-451.

[10]. Susanti, A., Soemitro, R.A.A. \& Suprayitno, H. (2017). "Identifikasi Awal Layanan Feeder di Tiap-Tiap Stasiun Menjadi Tempat Pemberhentian KA Penumpang di Kota Surabaya ", E-Journal Rekayasa Teknik Sipil (REKATS) UNESA, Vol. 1, No. 1, halaman 439-445.

[11]. Susanti, A., Soemitro, R.A.A. \& Suprayitno, H. (2017). Identifikasi Awal Volume Naik Turun Penumpang KA Komuter SUSI (Surabaya-Sidoarjo) di Tiap-Tiap Stasiun Pemberhentian Kota Surabaya. Prosiding Seminar Nasional Teknik Sipil III-2017. Jurusan Teknik Sipil, Fakultas Teknik. Universitas Negeri Malang. halaman 271280.

[12]. Tahir, A. (2005). Angkutan Massal Sebagai Alternatif Mengatasi Persoalan Kemacetan Lalu Lintas Kota Surabaya, Jurnal SMARTek. Vol. 3, No. 3, Agustus. halaman 169-182.

[13]. Tabassum, S., Tanaka, S., Nakamura,F., Ryo, A. (2017). Feeder Network Design for Mass Transit System in Developing Countries, Transportation Reseach Procedia, 25,

[14]. Utomo, E.B. (2016). “Analisis Kemacetan Lalu Lintas di Kota Surabaya”. Jurnal Swara Bumi UNESA, Bidang Pendidikan Geografis, FISH. UNESA, Vol. 3. No. 3, Halaman. 2029.

[15]. Yulianti, R.A. (2013). "Konsep Integrasi Moda Transportasi Publik Di Kota Surabaya Berdasarkan Preferensi Masyarakat", Program Magister Arsitektur ITS, Bidang Keahlian Manajemen Pembangunan Kota. 